\title{
Meaning Discrimination in Bilingual Venda Dictionaries*
}

\author{
Munzhedzi James Mafela, University of South Africa, Pretoria, Republic of \\ South Africa (mafelmj@unisa.co.za)
}

\begin{abstract}
Venda, one of the minority languages in South Africa, has few dictionaries. All are translational bilingual dictionaries meant for dictionary users who are non-native speakers of the language. Dictionary users find it difficult to use the bilingual Venda dictionaries because they are confronted with equivalents which they cannot distinguish. In most cases, the equivalents of the entry-words are provided without giving meaning discrimination. Without a good command of Venda and the provision of meaning discrimination, users will find it difficult to make a correct choice of the equivalent for which they are looking. Bilingual Venda dictionaries are therefore not helpful for dictionary users who are non-native speakers of the language. Devices such as giving illustrative examples, indicating parts of speech and adding etymology could be used to solve the problem of meaning discrimination in bilingual Venda dictionaries. This article highlights the problem of the absence of meaning discrimination and suggests solutions to future Venda lexicographers in this regard.
\end{abstract}

Keywords: BILINGUAL DICTIONARY, MEANING DISCRIMINATION, EQUIVALENCE, ENTRY-WORD, LEXICOGRAPHY, CULTURE, TRANSLATION, SOURCE LANGUAGE, TARGET LANGUAGE, SYNONYM, POLYSEMY

Opsomming: Betekenisonderskeiding in tweetalige Vendawoordeboeke. Venda, een van die minderheidstale in Suid-Afrika, het min woordeboeke. Almal is vertalende tweetalige woordeboeke bedoel vir woordeboekgebruikers wat nie moedertaalsprekers van die taal is nie. Woordeboekgebruikers vind dit moeilik om tweetalige Vendawoordeboeke te gebruik omdat hulle gekonfronteer word met ekwivalente wat hulle nie kan onderskei nie. In die meeste gevalle word die ekwivalente van die trefwoorde verskaf sonder om betekenisonderskeiding aan te dui. Sonder 'n goeie beheersing van Venda en die aanduiding van betekenisonderskeiding, sal gebruikers dit moeilik vind om die regte keuse van die ekwivalent waarvoor hule soek, te maak. Tweetalige Vendawoordeboeke is dus nie van hulp vir woordeboekgebruikers wat nie moedertaalsprekers van die taal is nie. Middele soos die gee van ophelderende voorbeelde, die aantoon van rededele en die byvoeging van etimologie kan gebruik word om die probleem van betekenisonderskeiding in tweetalige Vendawoordeboeke op te los. Hierdie artikel beklemtoon die probleem van die afwesigheid van betekenisonderskeiding en dien oplossings in dié verband aan die hand vir toekomstige Vendaleksikograwe.

* This article is a slightly revised version of a paper presented at the Eleventh EURALEX International Congress held at the Université de Bretagne-Sud, Lorient, France, 6-10 July 2004. 
Sleutelwoorde: TWEETALIGE WOORDEBOEK, BETEKENISONDERSKEIDING, EKWIVALENSIE, TREFWOORD, LEKSIKOGRAFIE, KULTUUR, VERTALING, BRONTAAL, DOELTAAL, SINONIEM, POLISEMIES

\section{Introduction}

A bilingual dictionary entails the description of two cultures because it deals with the translation of entry-words from the source language to the target language. Bilingual dictionaries may serve both target language and source language speakers. When a target language speaker wants to comprehend a foreign language he/she will consult a bilingual dictionary, and when a source language speaker wants to express him-/herself in a foreign language, he/she will also consult a bilingual dictionary. As Swanson (1983: 193) puts it, a bilingual dictionary can be useful and desirable to several kinds of people: students, travellers and linguists. According to Zgusta (1971: 294), the basic purpose of a bilingual dictionary is to co-ordinate the lexical units of one language with those of another language which are equivalent in lexical meaning. In many instances such co-ordinations are accompanied by problems on the part of dictionary users, especially if they are not native speakers of the target language. A user is less likely to know the meanings of foreign language words in the entries, and will therefore need information on how these foreign language words differ in meaning. Gouws (2000: 102) writes that this problem is a direct result of the traditional approach which sees a bilingual dictionary as a monofunctional product in which the treatment is restricted to the mere listing of a number of translation equivalents.

The translation equivalents of entry-words in a bilingual dictionary are usually of two types, i.e. translational and explanatory. A translational equivalent is a lexical unit which can immediately be inserted into the language, whereas an explanatory equivalent is of a general nature functioning well if the target language is the user's native tongue because it may suggest or elicit in him/her some other equivalent which fits the particular context with which he/ she is dealing (Al-Kasimi 1983: 60-61). Translational equivalence is favoured in a bilingual dictionary intended for speakers of the source language who want to express themselves in or translate into the foreign language.

Venda, one of the languages which were previously marginalised in South Africa, has very few dictionaries. Linguists did not pay much attention to Venda lexicography. In the past, the cultivation and development of a dictionary culture in the indigenous languages was minimal. in the past. As Van der Merwe (2003: 183) writes:

In order to cultivate and develop a dictionary culture in a country the existence of lexicography has to be recognised as a subject field. Lexicographical research has to lay the foundation for sound dictionary projects. Lexicographers have to be trained to compile user-friendly dictionaries that are theoretically sound. 
Hence there is a need to cultivate and develop a dictionary culture in Venda. At present, Venda has three English-Venda dictionaries (Phindulano: EnglishVenda Phrase Book, Phrase Book for English and Venda, and Dictionary of Basic English-Venda), one Afrikaans-Venda dictionary (Afrikaans-Venda Vocabulary and Phrase Book), one Venda-English dictionary (Venda Dictionary: Tshivenda-English) and one Venda-Afrikaans-English dictionary (Improved Trilingual Dictionary: Venda-Afrikaans-English). All the above-mentioned are bilingual dictionaries, except one (Improved Trilingual Dictionary: Venda-Afrikaans-English) which is partly bilingual and partly trilingual. The equivalents of entry-words in almost all of them are translational. With the exception of one reference dictionary (Venda Dictionary: Tshivenda-English), all are meant for foreigners, mainly missionaries (Phindulano: English-Venda Phrase Book, Phrase Book for English and Venda, Afrikaans-Venda Vocabulary and Phrase Book) and students (Improved Trilingual Dictionary: Venda-Afrikaans-English), who know very little or nothing at all about the Venda language or culture.

The objective of this article is to highlight the problem of the absence of meaning discrimination for the equivalents of the entry-words in the target language and the effect this has on dictionary users with reference to bilingual dictionaries in Venda. Suggestions about devices which can help solve this problem will be provided in the concluding remarks of the article.

\section{The choice of equivalents and equivalence discrimination}

An equivalent is a word or phrase in one language which corresponds in meaning to a word or phrase in another language (Prinsloo and De Schryver 2002: 162). Al-Kasimi (1983: 58) sees the major task of a bilingual lexicographer to find appropriate equivalents in the target language to the units of the source language. Some Venda dictionaries, especially early ones, provide users with word-for-word equivalents that comprise one source language entry and one equivalent in the target language. Hereunder are examples from the Phrase Book for English and Venda (Marole 1932).
(1) kidney
tswiyo
(2) elbow
lukudavhavha
(3) nail
nala

Newman (1980: 41) sees word-for-word equivalence as an ineffective second language learning method. However, a bilingual dictionary that does not provide more than one equivalent in the target language does not become a problem to the users because it does not involve meaning discrimination. Users of the Phrase Book for English and Venda do not encounter difficulty in choosing the equivalent of example (1). The equivalent of kidney is tswiyo in Venda. Tswiyo does not have synonyms or near synonyms. However, examples (2) and (3) can lead the user to wrong choices of equivalents because the entries in the source 
language are polysemous, and only one translation equivalent has been provided in each case. Both elbow and nail should have more than one equivalent characterised by different meanings. For example, the entries elbow and nail are defined in The Concise Oxford Dictionary of Current English (1990) as follows:

elbow: (a) joint between the forearm and the upper arm, (b) a short piece of piping bent through a right angle;

nail: (a) a small usu. sharpened metal spike with a broadened flat head, (b) horny covering on the upper surface of the tip of the human finger or toe, (c) fasten with nails.

In the entry elbow, the Venda equivalent is lukudavhavha (joint between the forearm and the upper arm); and in the entry nail, the equivalent is nala (horny covering on the upper surface of the tip of the human finger or toe). The other meanings of the entry-words have been omitted. If the user is looking for an equivalent of an entry-word which is found in a different context than the equivalent provided, then he/she will make a wrong choice of the equivalent. The provision of more equivalents, accompanied by equivalent discrimination is vital in this situation.

In some Venda bilingual dictionaries, users are confronted with several equivalents for one entry. They cannot discriminate between the equivalents because of the absence of the necessary information for the purpose of meaning discrimination. They therefore fail to make a correct choice of the equivalent. The notion of equivalent discrimination applies to all dictionaries that present one or more translation equivalents as part of the lexicographic treatment of the lemma sign (Gouws 2000: 99). As Al-Kasimi (1983: 67) writes:

When a person wants to say something in a foreign language, he might consult a bilingual dictionary. But instead of finding one word which expresses his meaning, he is frequently confronted with several words which he cannot distinguish one from another.

The equivalents themselves are the most important part of the entry. However, in the majority of cases, it does not suffice to indicate them alone, firstly because most of them have multiple meanings themselves, and secondly because they are only partial equivalents of the entry-word (Zgusta 1971: 329). Without additional information, the dictionary user will not be in a position to select the correct equivalent which fits the meaning in the context, unless he/she has a command of the target language.

The following are examples of dictionary entries from three EnglishVenda bilingual dictionaries which will assist in illustrating the above-mentioned problem. Examples (4)-(11) are from the Improved Trilingual Dictionary, examples (12)-(16) from the English-Venda Vocabulary, and examples (17) and (18) from the Afrikaans-Venda Vocabulary and Phrase Book.

(4) ape (n) (monkey) thoho(dzi); (vb) -edzisa 


$\begin{array}{ll}\text { (5) amputate } & \text {-tumula, -thukhula } \\ \text { (6) abduct } & \text {-tahisa (musadzi); -hwala } \\ \text { (7) abstain } & \text {-didzima } \\ \text { (8) bellow } & \text {-kuma } \\ \text { (9) buffalo } & \text { nari } \\ \text { (10) console } & \text {-fhembeledza, -khuthadza, -fhumudza, -lilisa } \\ \text { (11) difficulty } & \text {-vhuleme (abstr.), tshikundisi (zwi) } \\ \text { (12) abandon (n) } & \text { lața, u furalela } \\ \text { (13) swarm (n) } & \text { murivha, gogo } \\ \text { (14) act (v) } & \text { mushumo, mulayo } \\ \text { (15) boundary (n) } & \text { mukano, thanganyoni } \\ \text { (16) teacher (n) } & \text { mudededzi, mufunzi } \\ \text { (17) baard } & \text { dzindebvu, vhutambo } \\ \text { (18) berg } & \text { thavha }\end{array}$

From the examples cited above, it can be noticed that some entries have one equivalent each, i.e. examples (7), (8) and (9), while the others have more than one equivalent each. In the case of entries having one equivalent each, the dictionary user does not have a problem of distinguishing equivalents in Venda because there is only one meaning. In the case of entries having more than one equivalent, it is difficult for the source language dictionary user to select the correct equivalent relevant to the context because of multiple meanings which are synonyms or near synonyms.

In example (4), the entry ape is a noun and a verb at the same time. Although the compiler has given one part of speech, the entry-word has equivalents both as a noun and a verb in Venda. The parts of speech (n) and (vb) have been used to distinguish the meanings of the equivalents. As Iannucci (1983: 179) noted, meaning discrimination is sometimes effected by the designation of the part of speech of the entry word. In this example, it is easy for the dictionary user to select the correct equivalent because there is only one noun and one verb in the definition, i.e. thoho (monkey) and -edzisa (imitate). However, in examples (5) and (6), the dictionary user will have some difficulty in distinguishing the meanings of the given equivalents. When a user consults a bilingual dictionary, he/she wants to achieve an unambiguous identification and interpretation of the target language data and consequently the optimal retrieval of the target language information (Gouws 2000: 101). This is not possible in the examples given above. The lack of the inclusion of meaning discrimination impedes the user to choose the correct equivalent. In example (5), both equivalents -tumula and -thukhula are synonymous verb stems. The verb stem -tumula is associated with cutting something with an instrument such as a knife, whereas the verb stem -thukhula is associated with breaking something to 
pieces (e.g. a rope) by way of pulling. The selection of the equivalent will therefore depend on the context. As Gouws (2000: 110) mentions, users often need a co-text or other contextualising information to achieve equivalents. He further suggests that to ensure this, the lexicographer has to complement the translation equivalents with ample additional data. Without this additional data, it would be difficult for the user to select the correct equivalent. Meaning discrimination in this regard will involve the power of observing differences between meanings of equivalents of the same entry-word.

In example (6), abduct is defined by The Concise Oxford Dictionary of Current English (1990) as 'carry off or kidnap (a person) illegally by force or deception'. Unlawfulness is an essential element of abduction as evidenced in the definition (Mtuze 1990: 30). The equivalents of this entry-word, -tahisa and -hwala, are both verb stems. Their meanings are not related. The stem -tahisa means 'to cause to elope', whereas the stem -hwala generally means 'to carry something'. When a girl is caused to elope, she might go of her own volition, especially if there is some consent between her and the man. The girl may also be forced to accompany the man. Even if there were an agreement between the girl and the man, the process of eloping is considered an improper marriage procedure in Venda society. The context in which the entry-word abduct is used, will therefore be the guideline in the choice of the correct equivalent because -tahisa and -hwala have different meanings. Meaning discrimination is therefore important in order to distinguish between the two equivalents which belong to the same part of speech and are near synonyms. For the user to be able to make the correct choice of translation equivalents in this situation, he/she has to be familiar with the Venda language and culture.

Worse still is the situation when one encounters an entry-word with four or more equivalents which all belong to the same word category and are all synonymous, as in example (10). The equivalents given are all verb stems.

$\begin{array}{ll}\text {-fhembeledza } & \text { persuade, coax } \\ \text {-khuthadza } & \text { appease; pacify } \\ \text {-fhumudza } & \text { silence; comfort, console } \\ \text {-lilisa } & \text { make cry; console }\end{array}$

The stem -fhembeledza has a different meaning from the other equivalents. When one persuades a person, he/she does not console him/her. The word persuade is defined by Webster's New World Dictionary as 'to cause to do or believe something, especially by reasoning and urging'. Although the stems -fhumudza, -khuthadza and -lilisa are related, their meanings are not exactly the same. For example, the other meaning of -lilisa is 'to make to cry'. Dictionary users will find it difficult to choose the correct equivalent. The selection of the correct equivalent will depend on the context, and this will be elucidated by the provision of meaning discrimination. 
In example (12), the entry-word abandon has two equivalents in Venda, -lata and -furalela which are both verb stems. Van Warmelo (1989: 61) translates -furalela as 'turn one's back upon', whereas Wentzel and Muloiwa (1982: 17) translate -furalela as 'turn one's back upon; ignore'. On the other hand, -lata means 'to throw away, discard or abandon'. From the definitions of the two equivalents shown above, it is clear that the equivalents are not absolutely synonymous. The same applies to example (13), swarm, which has two near synonymous equivalents, murivha and gogo, both nouns. The noun murivha refers to a group of birds flying together, while the noun gogo refers to many people gathered in one place. These meanings are not interchangeable, however. Therefore, the lack of additional information to define the equivalents impedes the correct choice within a given context.

The dictionary user will find example (14) problematic. The entry-word act has mushumo and mulayo as its equivalents. Act can be used as a noun or as a verb. However, it is only shown as a verb, but all its Venda equivalents are nouns, their word category not being indicated. Mushumo refers to 'work' or 'function', whereas mulayo refers to 'rule of law'. The context in which the entryword act is used will guide the dictionary user to the choice of the correct equivalent. But without meaning discrimination, it will be difficult for a dictionary user to make the correct choice. The equivalent verb stems of the entryword act in Venda should have been -tamba (play), -edza (mimic or imitate). However, these equivalents are not included in the definition of the entryword. The incorrect entries provided will therefore mislead the user in his/her choice of the equivalents.

In example (15), mukano is a dividing line (boundary), whereas thanganyoni refers to the intersection (e.g. of rivers). The equivalent thanganyoni cannot be regarded as a boundary without considering the context in which it is used. In example (16), mudededzi refers to a teacher who teaches pupils or students in class, whereas mufunzi is a preacher in the church. Both, however, are near synonymous equivalents of the entry-word teacher. As with example (13), it would be difficult to make a correct choice of an equivalent without the necessary information about the two equivalents. For the dictionary user to choose correctly between these translations, meaning discrimination is important.

As in the dictionaries considered so far, co-ordination of source and target language items can impede the correct choice of a translation equivalent in the Afrikaans-Venda Vocabulary and Phrase Book. Users of this bilingual dictionary do not encounter difficulty in the choice of a translation equivalent in example (18), because the relation is characterised by one entry (i.e. berg which means 'mountain') and one equivalent in Venda (i.e. thavha). There are no synonyms or near synonyms of the equivalent thavha. However, the user could find it difficult to make a correct choice in example (17). The entry-word baard is given its corresponding Venda equivalents dzindebvu and vhutambo, both near synonymous nouns. Dzindebvu is the plural form of ndebvu, which refers to beard (hair growing on the lower part of a man's face). On the other hand, vhutambo is a polysemous word which in this instance refers to pubic hair. No additional 
information which would enable the dictionary user to discriminate these meanings has been provided for these equivalents. Therefore, the dictionary user may make a wrong choice for the equivalent of the entry-word baard. Both equivalents refer to hair, but hair found on different parts of the body. Furthermore, dzindebvu is a characteristic of males, whereas vhutambo is a characteristic of both males and females. Without additional information the user may choose the wrong translation equivalent for a particular context.

The above discussion of examples from three different dictionaries reveals that meaning discrimination is very important in bilingual dictionaries. As Gouws (2000: 99) accentuates, the more target language information included in a dictionary, the better the chances should be of an unambiguous transfer of information.

\section{Possible solutions}

Dictionary users need entries which cover all the meanings they require, i.e. meanings which provide them with the necessary information to make appropriate well-informed lexical choices (Scholfield 1999). The ideal bilingual dictionary would anticipate every conceivable need of the prospective user. It would provide for each word or expression in the source language just the right translation in the target language, including, most importantly, the one needed for a particular passage in hand (Hartmann 1999: 7). As indicated above, Venda bilingual dictionaries are not helpful in this regard. The treatment of meaning discrimination in Venda bilingual dictionaries is unsatisfactory. In order to understand sentences, users need to know the meaning of words. The provision of more information about the equivalents in the target language is important, as stressed by Gouws (2000: 104):

The average user of bilingual dictionaries needs much more information in the comment on semantics to utilise the dictionary as a practical instrument. Lexicographers will have to enhance the possibilities for equivalent discrimination.

This additional information will enable dictionary users to interpret the meaning of utterances in the context in which they are made.

According to Al-Kasimi (1983), meaning discrimination is necessary in the following cases:

(a) When the source language has one meaning for which the target language has a polysemous equivalent.

(b) The source language is polysemous, and for each of its senses the target language has two or more polysemous words.

Additional information can be given in different ways. To achieve meaning discrimination, use can be made of different devices such as providing short 
definitions of equivalents, indicating parts of speech, adding etymology and usage labels, and giving context words and phrases, and illustrative examples. Of these, illustrative examples, parts of speech and etymology are vital devices for meaning discrimination in bilingual dictionaries.

Examples can be used to illustrate the meaning of the word defined. According to Al-Kasimi (1983: 91), the primary function of illustrative examples in dictionaries in general and bilingual dictionaries in particular is to capture the user's interest by showing the word in a live context, and to enhance his/her understanding of the grammatical and semantic rules governing the usage of the word by showing these rules in action. These illustrative examples can further give the dictionary user some notion of the foreign culture he/she is encountering. Illustrative examples, phrases and sentences can be utilised to show how the equivalents are used in context.

The designation of the part of speech of both the entry word and the equivalents can also help to distinguish between the equivalents. Jackson (1985: 55) says:

If a dictionary gives no other information of grammatical nature, it is expected to indicate which part-of-speech or word class a lexical item belongs to, i.e. whether it is classed as a noun or as a verb or adjective, etc.

Although the word-class label does not provide sufficient information of a grammatical kind, it provides basic information about the syntactic operation of a lexical item. The grammatical identity of words such as noun, verb, adjective, etc., is given for all entries and derivatives to aid clarity.

Etymology is another device which can help users of bilingual dictionaries to obtain a clear understanding of the present meanings of words. In this case, the historically variable sources of the formation of a word and the development of its meaning are provided.

\section{Conclusion}

With the introduction of lexicography units for the indigenous languages in South Africa by the Pan South African Language Board, it is hoped that future lexicographers of the indigenous languages in general and Venda in particular will attend to the problem of meaning discrimination in bilingual dictionaries to make them more useful to users. This could be achieved by training lexicographers to compile user-friendly dictionaries which will be of value to both students, travellers and linguists. As indicated above, the present Venda bilingual dictionaries are not user-friendly. Al-Kasimi (1983: 68) accentuates:

The bilingual dictionary should provide meaning discriminations which enable the user to select the appropriate equivalent or the proper sense of an equivalent. And unless the problem of meaning discrimination is solved systematically, the bilingual dictionary cannot be a dependable guide to the proper equivalents. 
Attempts to achieve equivalent discrimination will increase the communicative success of the bilingual dictionary.

\section{References}

\section{Dictionaries}

Allen, R.E. (Ed.). 1990. The Concise Oxford Dictionary of Current English. Oxford: Clarendon Press.

Guralnik, D.B. (Ed.). 1981. Webster's New World Dictionary of the American Language. New Jersey: Simon and Schuster.

Marole, L.T. 1932. Phrase Book for English and Venda. Sibasa: Marole Book Depot.

Marole, L.T. 1954. English-Venda Vocabulary. Sibasa: Marole Book Depot.

Marole, L.T. 1955. Afrikaans-Venda Vocabulary and Phrase Book. Sibasa: Marole Book Depot.

Van Warmelo, N.J. 1989. Venda Dictionary: Tshivenda-English. Pretoria: J.L. van Schaik.

Wentzel, P.J. and T.W. Muloiwa. 1982. Improved Trilingual Dictionary: Venda-Afrikaans-English. Pretoria: University of South Africa.

\section{Other Sources}

Al-Kasimi, A.M. 1983. Linguistics and Bilingual Dictionaries. Leyden: E.J. Brill.

Gouws, R.H. 2000. Strategies in Equivalent Discrimination. Mogensen, J.E. et al. (Eds.). 2000. Proceedings of the Ninth International Symposium on Lexicography: 99-111. Tübingen: Max Niemeyer.

Hartmann, R. 1999. Lexical Reference Books - What Are the Issues? National Journal of Lexicography 12(1): 5-12.

Iannucci, J.E. 1983. Meaning Discrimination in Bilingual Dictionaries. Linguistics Honours: Volume 3: Equivalence, Bilingual Dictionaries and Translation: 177-192. Pretoria: Unisa.

Jackson, H. 1985. Grammar in the Dictionary. Ilson, R. (Ed.). 1985. Dictionaries, Lexicography and Language Learning: 53-59. Oxford: Pergamon Press.

Mtuze, P.T. 1990. Problems of Equivalence and Adequacy in a Trilingual Context. South African Journal of Linguistics 8(1): 30-32.

Newman, A. 1980. Mapping Translation Equivalence. Louvain: Acco.

Prinsloo, D.J. and Gilles-Maurice de Schryver. 2002. Reversing an African-Language Lexicon: The Northern Sotho Terminology and Orthography No. 4 as a Case in Point. South African Journal of African Languages 22(2): 161-185.

Scholfield, P. 1999. Dictionary Use in Reception. International Journal of Lexicography 12(1): 13-34.

Swanson, D.C. 1983. The Selection of Entries for a Bilingual Dictionary. Linguistics Honours, Volume 3: Equivalence, Bilingual Dictionaries and Translation: 193-207. Pretoria: Unisa.

Van der Merwe, M. 2003. Towards the Creation of a Dictionary Culture in South Africa. De Schryver, Gilles-Maurice (Ed.). Sixth International TAMA Conference: Conference Proceedings: 183-188. Pretoria: (SF)2 Press.

Zgusta, L. 1971. Manual of Lexicography. The Hague/Paris: Mouton. 